The Insecure American 
This page intentionally left blank 


\title{
The Insecure American
}

How We Got Here and What We Should Do about It

\author{
Edited by \\ Hugh Gusterson \\ and Catherine Besteman
}

Foreword by Barbara Ehrenreich

\section{ㄸ}

UNIVERSITY OF CALIFORNIA PRESS

Berkeley Los Angeles London 
University of California Press, one of the most distinguished university presses in the United States, enriches lives around the world by advancing scholarship in the humanities, social sciences, and natural sciences. Its activities are supported by the UC Press Foundation and by philanthropic contributions from individuals and institutions. For more information, visit www.ucpress.edu.

University of California Press

Berkeley and Los Angeles, California

University of California Press, Ltd.

London, England

(C) 2010 by The Regents of the University of California

Every effort has been made to identify and locate the rightful copyright holders of all material not specifically commissioned for use in this publication and to secure permission, where applicable, for reuse of all such material. Credit, if and as available, has been provided for all borrowed material either on-page, on the copyright page, or in an acknowledgment section of the book. Errors, omissions, or failure to obtain authorization with respect to material copyrighted by other sources has been either unavoidable or unintentional. The author and publisher welcome any information that would allow them to correct future reprints.

\section{Library of Congress Cataloging-in-Publication Data}

The insecure American / edited by Hugh Gusterson and Catherine Besteman.

p. $\quad \mathrm{cm}$.

Includes bibliographical references and index.

ISBN 978-0-520-25969-o (cloth : alk. paper)—ISBN 978-0-520-25971-3 (pbk. : alk. paper)

1. United States-Politics and government-21st century. 2. United States-Social conditions-21st century. 3. Security (Psychology)United States. 4. Nationalism-United States. I. Gusterson, Hugh. II. Besteman, Catherine Lowe.

JK275.I57 2010

$973.93-\mathrm{dc} 22$

2009015363

Manufactured in the United States of America

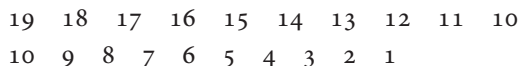

This book is printed on Cascades Enviro 100, a 100\% post consumer waste, recycled, de-inked fiber. FSC recycled certified and processed chlorine free. It is acid free, Ecologo certified, and manufactured by BioGas energy. 
To Stanley Ann Dunham 
This page intentionally left blank 